\title{
TP53 Mutation Status by Sequencing
}

National Cancer Institute

\section{Source}

National Cancer Institute. TP53 Mutation Status by Sequencing. NCI Thesaurus. Code C157238.

An indication that the presence or absence of TP53 gene mutations was determined using sequencing techniques. 